\title{
NOTE ON OTOHIME, A NEW GENUS OF GURNARDS.
}

\author{
By David Starr Jordan and Edwin Chapin Starks, \\ of Stanford University, California.
}

The species of gurnard described by Schlegel as Trigla hemisticta may be considered as the type of a new genus, Otohime, distinguished from Chelidonichthys ("pictipinnis," kumu, hirundo) especially by the absence of the dorsal armature characteristic of Chelidonichthys. The scales are very small, the lateral line unarmed, and there are no sharp-edged bony spines along the base of the dorsal fins. In place of these there are about three flattish bucklers along each side of the base of the spinous dorsal, and one buckler lunate in form across the median line in front of the first spine. The dorsal spines are strong, and the soft dorsal and anal are much shorter than in Chelidonichthys. The opercle ends in a very long spine. Vomer with few teeth; none on the palatines. The single known species Otohime hemisticta is rare in Japan, only one specimen having been seen by us.

Otohime in Japanese mythology is a goddess of fishes.

The genera of Triglidæ may be thus compared:

KEY TO GENERA.

a. Scales relatively large; teeth on vomer and none on palatines; a row of spinous bucklers along base of dorsal . . . . . . . . . . . . . . Lepidotrigla. aa. Scales relatively small.

$b$. Palatines without teeth.

c. Lateral line armed with spines or bony cross plates; teeth on vomer... Trigla. cc. Lateral line unarmed.

d. Base of both dorsals with a series of shields, each ending in a sharp spine directed backward. Opereular spine small; soft dorsal and anal long. Dorsal rays, Ix-16; anal, 15; no anal spine.......... Chelidonichthys.

$b b$. Base of dorsal with blunt shields along base of spinous dorsal only; base of soft dorsal unarmed; opercular spine very long; soft dorsal and anal short; dorsal rays vin-10, anal I, 11; the anal spine distinct... Otohime.

$b b$. Palatines with teeth; no spinous plates along dorsal base nor along lateral line. e. Head spinous above .............................. . Prionotus.

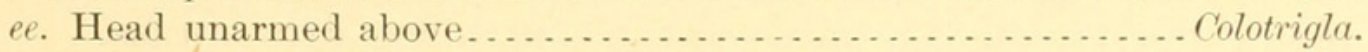


OTOHIME HEMISTICTA (Schlegel).

The following are the characters of the type species of Otohime. Depth at occiput, $4 \frac{1}{2}$ in length to base of caudal; head (without opercular or rostral spines) $2 \frac{3}{4}$. Eye, 3 in head; maxillary, 2. Dorsal, VIII-10; anal I, 11; scales, 105.

Anterior profile steep and straight from eyes to tip of snout. Supraorbital rim produced; interorbital broad and concave; its width equal to diameter of orbit.

Maxillary reaching to below middle of eye; mandible slightly curved up at its tip and shutting entirely within premaxillary teeth; teeth in very narrow bands, those on lower jaw in a narrower band than on upper; vomer of the specimen at hand without teeth, but marks on the bone show their probable former presence. A single rostral spine on

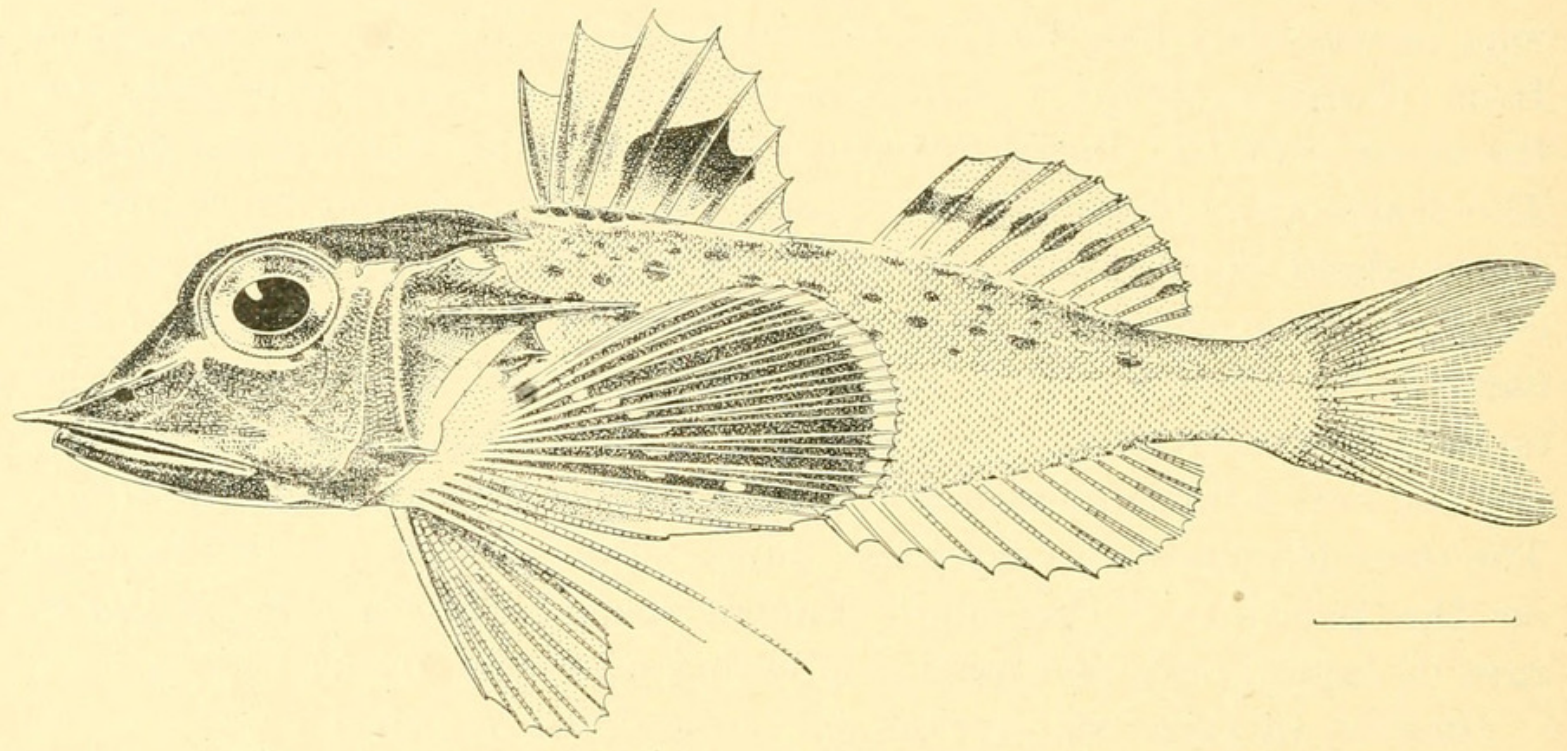

OTOHIME HEMISTICTA.

each side, equal in length to vertical diameter of pupil. Edge of preorbital finely serrate, the serræ extending along outer edge of rostral spine. A sharp spine is directed backward from temporal region, and a very long one from opercle continued as a ridge anteriorly nearly across opercle; length of spine from posterior edge of opercle equal in length to diameter of eye; a sharp spine on posterior edge of preopercle near its angle; a triangular spine on posterior edge of supraclavicle. The gill arches of our specimen have been removed.

Fine irregular scales cover the trunk; a crescentic naked area between dorsal and head; anothẻr naked area behind pectoral and ventral; round imbedded scales sparsely cover the breast; no scales on fins. A crescent-shaped rugose plate in front of base of first dorsal spine, and three round or elliptical ones behind it on each side of spinous dorsal, the last between the fourth and fifth spines.

Dorsal spines stiff and sharp; the fourth the longest, equal in length to the maxillary; when fin is depressed the fourth and fifth spines 
reach beyond the others. Dorsal rays slender, once divided, rather widely spaced; the longest equal to vertical diameter of orbit. Anal as high as soft dorsal and extending a little posterior to it. Caudal lunate, its angles sharp. Pectoral reaching to opposite base of third anal ray, the three detached rays slender and pointed, the upper one but little shorter than the other pectoral rays, the lower one not reaching to tip of ventral. Ventral not quite reaching to vent.

Our specimen is apparently badly faded. It is now light gray above, abruptly white below middle of side; dark brown round and elliptical spots are scattered sparsely and irregularly over upper part of side. Spinous dorsal with a large clear-cut dark brown spot from fourth to sixth spines, fin otherwise transparent and colorless; soft dorsal with a row of brown spots, one on each ray; ventrals, anal, caudal, and detached pectoral rays colorless. Outer surface of pectoral with white rays and dark brown membrane bordered with white behind; when fin is closed the white of the rays only shows; inner surface more uniform dark brown and darker than outer surface, the rays lighter only toward their tips, the white border at posterior margin of fin more conspicuous, two rows of irregular milk-white spots across fin on the rays, encroaching on the membrane but slightly; the anterior row of large irregular spots the posterior of only three or four small round spots.

The specimen from which this description is drawn was brought by Mr. Pierre L. Jouy, from Yokohama. It probably came from Misaki or Awa, outside the Bay of Tokyo. It is $195 \mathrm{~mm}$. in entire length.

The species of Triglidæ known from Japanese-waters are the following, most of them described by Jordan and Starks in the Bulletin of the U. S. Fish Commission for 1902:

1. Otohime hemisticta (Schlegel) Yokohama.

2. Chelidonichthys kumu (Lesson and Garnot). (Trigla spinosa McClelland, Jour. Cale. Nat. Hist., IV, p. 396. Cheledonichthys punctipinnis Kaup, Archiv. f. Naturg. 1873. p. 87. The locality stated, evidently by error, as Barbados.)

Found throughout southern and middle Japan, very common; also in New Zealand and Australia.

3. Lepidotrigla güntheri Hilgendorf. (Lepidotrigla longispinis Steindachner.) Suruga Bay, Totomi Bay, Yokohama.

4. Lepidotrigla abyssalis Jordan and Starks, Suruga Bay.

5. Lepidotrigla smithi Regan. (Ann. Mag. Nat. Hist., 1905, p. 22.) Inland Sea of Japan; not seen by us.

6. Lepidotriglamicroptera Günther. (Lepidotrigla strauchii Steindachner.) Aomori, Hakodate, Tsuruga, Matsushima, Hiroshima.

7. Lepidotrigla japonica (Bleeker). (? Lepidotrigla serridens Hilgendorf) Misaki.

8. Lepidotrigla alata (Houttuyn), (Trigla burgeri Schlegel), Nagasaki, etc. 


\section{$2 \mathrm{BHL}$ Biodiversity Heritage Library}

Jordan, David Starr and Starks, Edwin Chapin. 1907. "Note on Otohime, a new genus of gurnards." Proceedings of the United States National Museum 32, 131-133.

View This Item Online: https://www.biodiversitylibrary.org/item/53434

Permalink: https://www.biodiversitylibrary.org/partpdf/51866

\section{Holding Institution}

Smithsonian Libraries

\section{Sponsored by}

Smithsonian

\section{Copyright \& Reuse}

Copyright Status: Public domain. The BHL considers that this work is no longer under copyright protection.

This document was created from content at the Biodiversity Heritage Library, the world's largest open access digital library for biodiversity literature and archives. Visit BHL at https://www.biodiversitylibrary.org. 